\title{
Effect of Crude Extract and its Semi Purified Constituents from Guaraná Seeds [Paullinia Cupana Var. Sorbilis (Mart.) Lucke on Cognitive Performance in Morris Water Maze in Rats
}

\author{
Fernanda Jacques Otobone, Andréia Conegero Sanches, Rosangela Lika Nagae, Juliana \\ Vanessa Colombo Martins, Simoni Obici, João Carlos Palazzo de Mello and Elisabeth \\ Aparecida Audi* \\ Departamento de Farmácia e Farmacologia; Universidade Estadual de Maringá; Av. Colombo, 5790; zona 7; \\ 87020-900; Maringá - PR - Brasil
}

\begin{abstract}
The effect of crude lyophilized extract (EBPC) and the semi-purified constituents (EPA and EPB) of $\underline{\text { Paullinia }}$ cupana (guaraná) seeds long-term administered in rats by gavage at different doses was studied on cognitive behavior in rats. EBPC (30.0 mg/kg) and EPA $(2.0 \mathrm{mg} / \mathrm{kg})$, but not EPB (2.0 or $4.0 \mathrm{mg} / \mathrm{kg})$ showed a smaller escape latency to find the emerged platform in Morris water maze test (MWMT), showing nootropic-like effect in normal rats, and in scopolamine induced amnesia rats compared to their controls (saline $+0.2 \%$ Tween 80) group. These extracts had no significant effect in open field test (OFT). Caffeine did alter escape latency in MWMT only in scopolamine induced amnesia rats and increased the crossings number in OFT, showing significant stimulant effect. Chronic treatment showed the same increase in body weight and average lifespan indicating a low toxicity for the extracts.
\end{abstract}

Key words: Cognitive effects, guaraná, Morris water maze, Paullinia cupana

\section{INTRODUCTION}

In the recent years, there has been a rise in the interest of scientific community and pharmaceutical laboratories to explore the pharmacological actions of herbs. Several plants have been reported to posses nootropic activity (Nadkarni, 1996). Guaraná (Paullinia cupana var. sorbilis (Mart.) Ducke Sapindaceae) is a plant found in the central Amazon basin region in Brazil. Guaraná seeds contains high concentration of xanthic bases (3.0-6.0\%) as caffeine (1,3,7-trimethylxanthine), and trace amounts of theophylline and theobromine. It also contains high concentrations of polyphenols or saponines (7\%) as flavan-3-ols [catechin and epicatechin] and other condensed tannins (Henman 1982, Benowitz, 1990). Guaraná has been popularly used as stimulant of the central nervous system (CNS) in cases of intelectual and physical stress, as antidiarrheic, diuretic and antineuralgic agent (Benowitz, 1990). The xanthic bases of guaraná, however, do not explain all of these therapeutic actions. Rats treated with extracts of guaraná, but not with caffeine at a dose similar to

\footnotetext{
${ }^{*}$ Author for correspondence
} 
that found in guaraná extract, had shown antioxidant (Mattei et al, 1998) and anti-amnesia effects (Espinola et al, 1997) in a passive avoidance test. Thus, its effects could to be due to the other(s) substance(s) than xanthines contents in extract.

Saponins and tannins are known as substances that have antioxidant action (Simeray et al, 1982; Yoshizawa et al, 1987). Saponins from Panax ginseng (Ying et al, 1994) and the total saponin isolated from red ginseng (Lee et al, 2000) are the active substances responsible for enhancing cognitive behavior. Despite of widespread there are only a few experimental data up to now avaliable describing the constituents responsible by the different popular uses. Thus, the aim of this work was to investigate the effects of the chronic treatment of the crude extract (EBPC) or of its semi purified (EPA and EPB) constituints from the seeds of Paullinia cupana (guaraná) on cognitive behavior in rats. The experimental model chosen were the Morris water maze (MWM).

\section{MATERIALS AND METHODS}

\section{Plant material}

The guaraná seeds were collected near Maués, Amazonas State, Brazil. The samples were dried and stabilized using facilities provided by EMBRAPA. The dried seeds were ground using a grinder Tecnal (model TE-048). A voucher plant specimen (\#PR9065) was deposited with the Herbarium of the State University of Maringá (HUM). Species identification was performed by Dr. Cássia Mônica Sakuragui.

\section{Extracts and drugs}

An extract was prepared from the seeds $(1000 \mathrm{~g})$ and after removal of the organic solvent, the remaining solid material was lyophilized (EBPC patent pending \# PI 0006638-9). The semipurified, lyophilized extracts were obtained from EBPC (158 g): EPA (44 g) and EPB (53 g) (patent pending \# PI 0006638-9). EBPC (30.0 or 60.0 $\mathrm{mg} / \mathrm{kg}$ ), EPA (2.0 or $4.0 \mathrm{mg} / \mathrm{kg}$ ) and EPB (2.0 or $4.0 \mathrm{mg} / \mathrm{kg}$ ) extracts were solubilized and administered by gavage in rats. Caffeine (10.0 $\mathrm{mg} / \mathrm{kg}$, Sigma) and scopolamine $(2.0 \mathrm{mg} / \mathrm{kg}$, Sigma) were administered by intraperitoneal (i.p.) rout. The control group was treated with the vehicle used to dissolve all solutions used $(0.9 \%$ $\mathrm{NaCl}$ containing $0.2 \%$ Tween 80 ).

\section{Animals}

Male Wistar rats (50-55 days old, 220-250 g) housed 5 per cage constant room temperature (22$23{ }^{\circ} \mathrm{C}$ ) under a $12 \mathrm{~h}$ light-dark cycle with free access to food and water were used in the experiments. The animals were treated once daily for 40 days with the crude extract EBPC, EPA or EPB. The procedures adopted were approved by the UEM Ethical Committee (\# 084-02/COBEA) and followed by the norms recommended as international guiding principles for Biomedical Research Involving Animals (CIMS), Geneva, 1985.

\section{Morris water maze test (MWMT)}

A spatial memory was performed by the method of Morris (1984). The test consisted of a round water tank $(150 \mathrm{~cm}$ in diameter $X 40 \mathrm{~cm}$ in height) with opaque water ( $25 \mathrm{~cm}$ in height) containing a temperature of about $22 \pm 1{ }^{\circ} \mathrm{C}$. The pool was placed in a room with fixed furniture and posters able to function as extramaze cues. The maze was divided into four equal quadrants (south-west, north-west, nort-est, south-east). A incolor glass platform $(23.5 \mathrm{~cm}$ height and apical diameter of 8 $\mathrm{cm})$ was placed $1 \mathrm{~cm}$ below the water surface, always midway between the center and rim of the pool in the target quadrant, so that it was invisible at the water surface.

Rats were trained to find the hidden platform at a fixed location in space. The parameter evaluated was the latency to find the platform (escape latency). On the first day, the rats were given five trials sessions of 2 min. with a inter-trial interval of $30 \mathrm{~min}$. In each trial, once the rats found the platform and rested upon it, they were permitted to remain for $30 \mathrm{~s}$. If the rat did not find the platform within the maximal time, it was placed on it for 30 $\mathrm{s}$ and then removed from the pool. The escape latency was stabilized between 3-5 trial sessions, when the rats learned to take relatively direct paths to the hidden platform. The escape latency was not averaged in the trial sessions. At $24 \mathrm{~h}$, the rats were submitted to a test session to evaluate the spatial retention memory. The test session had a maximal time of $2 \mathrm{~min}$. and was recorded by video camera. All animals were chronically treated with control, caffeine or test drugs (EBPC, EPA or EPB) by gavage. Control or scopolamine (2.0 $\mathrm{mg} / \mathrm{kg}$ ) was administered by i.p. rout $30 \mathrm{~min}$ before the test session. 


\section{Open-field test (OFT)}

After 24 hours, each animal was placed in the OFT. During a $5 \mathrm{~min}$. period, the number of squares visited (four feet placed in the same square) was registered using Royce's validation criteria (1977).

\section{Chronic effect of guaraná extracts on body} weight increase and mortality

The same experimental groups used in the above experiments were assessed for body weight increase and mortality over the course of 40 days treatment. After this period, the rats were killed and the organs were removed for observation and weighing. Body weight was measure every week.

\section{Data Analysis}

Results are expressed as the mean \pm SEM for each group. A one-way analysis of variance (ANOVA), followed by Dunnett's test for multiple comparisons or the t-test was used. Effects or differences of the control group (saline $+0.2 \%$ Tween 80) were considered significant at $\mathrm{p} \leq 0.05$.

\section{RESULTS}

Fig. 1 shows the results observed after chronic administration (40 days) by gavage of control
$(\mathrm{NaCl}+0.2 \%$ Tween 80$)$, EBPC crude guaraná extract $(30.0$ or $60.0 \mathrm{mg} / \mathrm{kg})$ or caffeine $(10.0$ $\mathrm{mg} / \mathrm{kg})$ associated to control $(\mathrm{NaCl}+0.2 \%$ Tween 80 ) or scopolamine $(2.0 \mathrm{mg} / \mathrm{kg})$ administered by i.p. rout, $30 \mathrm{~min}$ before test session in rats submitted to the MWMT. Escape latency to find the platform was significantly reduced $(\mathrm{p}<0.05)$ by $30.0 \mathrm{mgEBPC} / \mathrm{kg}$ dose + control when compared to control + control. Control + scopolamine treated rats induced significant increase $(p<0.05)$ in this parameter compared to control + control. The association of scopolamine and EBPC (30.0 or $60.0 \mathrm{mg} / \mathrm{kg}$ ) or caffeine produced similar results to control + control $(\mathrm{F}(7$, $48)=6.678, \mathrm{p}=0.0001$ ).

Fig. 2 show that $2.0 \mathrm{mgEPA} / \mathrm{kg}$ dose, but not $4.0 \mathrm{mgEPA} / \mathrm{kg}$ dose associated to control, reduced $(p<0.05)$ the escape latency in the MWMT when compared to control + control. Scopolamine + control produced significant spatial memory deficit $(\mathrm{p}<0.01)$, showing maximal time in the pool $(120 \mathrm{~s})$ without find the platform. The association of scopolamine and EPA (2.0 or 4.0 $\mathrm{mg} / \mathrm{kg}$ ) produced similar results to control + control $(\mathrm{F}(5,36)=7.947, \mathrm{p}<0.0001)$.

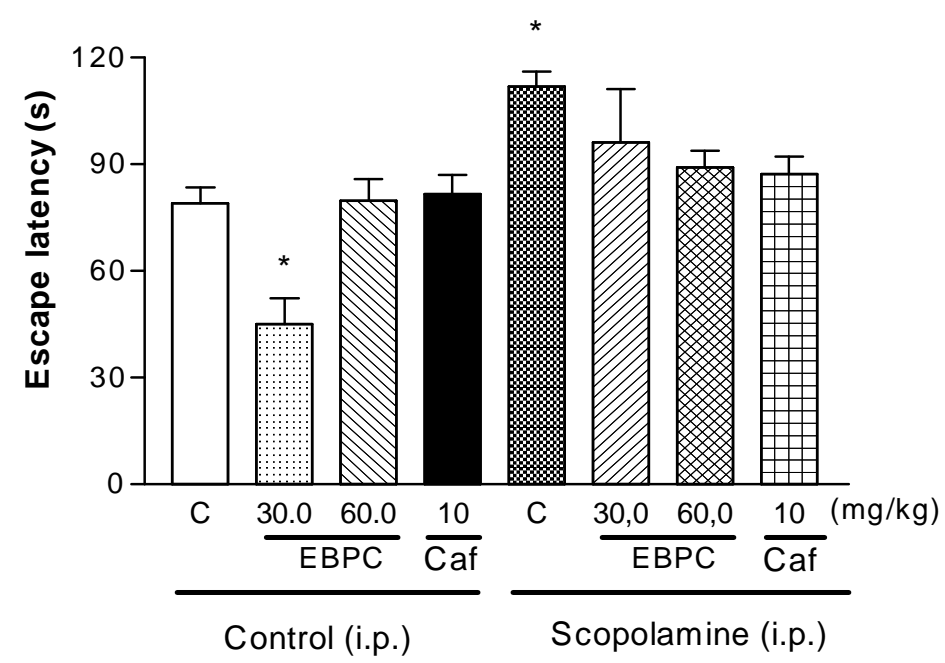

Figure 1 - Mean $( \pm$ SEM) represents escape latency in rats submitted to the Morris water maze test after chronic treatment (40 days) for control (C, saline $+0.2 \%$ Tween 80 ), EBPC $(30.0$ or $60.0 \mathrm{mg} / \mathrm{kg})$ or caffeine $(10.0 \mathrm{mg} / \mathrm{kg})$ by gavage associated to control or scopolamine $(2.0 \mathrm{mg} / \mathrm{kg})$ by i.p. rout $30 \mathrm{~min}$ before test session. ANOVA followed by Dunnett's test showed a significant treatment effect $* \mathrm{p}<0.05,(n=7)$. 
Table 1 showed that EBPC $(30.0 \mathrm{mg} / \mathrm{kg})$, EPA $(2.0$ and $4.0 \mathrm{mg} / \mathrm{kg})$ or EPB $(2.0$ and $4.0 \mathrm{mg} / \mathrm{kg})$ in MWMT did not alter number of crossings in the OFT. Caffeine increased $(\mathrm{p}<0.05)$ the number of crossings compared to the control $(F(6,42)=$ 2.356, $\mathrm{p}=0.0473$ ).

No changes were found after $t$-test statistical analysis in the animals body weight and mortality after chronic administration of EBPC, EPA, EPB or caffeine. Yet, the organs evaluated showed no differences in weight and appearance (data not shown).

\section{DISCUSSION}

In the present study, rats chronically treated with EBPC showed betterment in cognitive behavior in normal rats in MWMT. In addition, the semipurified component, EPA, reproduced EBPC effect in the MWMT. Chronic administration of EBPC or EPA was able to protect rats from amnesia effect of scopolamine.

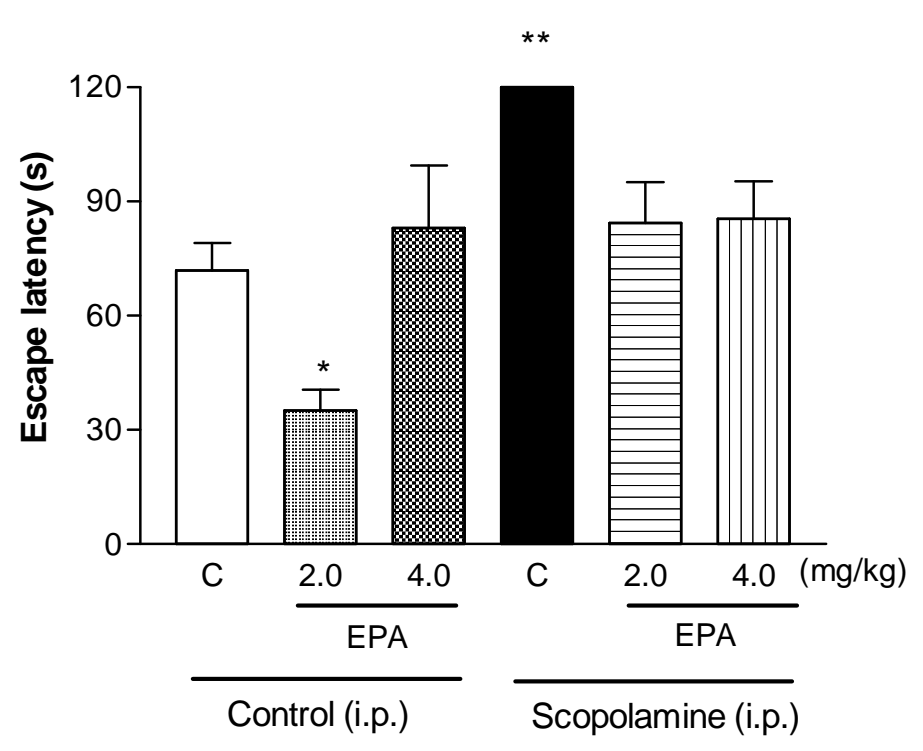

Figure 2 - Mean $( \pm$ SEM) represents escape latency in rats submitted to Morris water maze test after chronic treatment for control rats $(\mathrm{C}$, saline $+0.2 \%$ Tween 80$)$ or EPA (2.0 or $4.0 \mathrm{mg} / \mathrm{kg})$ by gavage and control $(\mathrm{C}$, saline $+2 \%$ Tween 80$)$ or scopolamine $(2.0$ $\mathrm{mg} / \mathrm{kg}$ ) by i.p. rout $30 \mathrm{~min}$ before test session. ANOVA followed by Dunnett's test revealed significant differences $* \mathrm{p}<0.05, * * \mathrm{p}<0.01,(\mathrm{n}=7)$.

Table 1 - Effects of chronic treatment by gavage of EBPC (30.0 mg/kg), EPA (2.0 and $4.0 \mathrm{mg} / \mathrm{kg})$, EPB (2.0 and $4.0 \mathrm{mg} / \mathrm{kg}$ ) and caffeine $(10.0 \mathrm{mg} / \mathrm{kg})$ in crossings number in OFT after chronic administration. Saline $+0.2 \%$ Tween 80 was utilized as control $(n=7)$.

\begin{tabular}{c|c|c}
\hline Treatment & Dose $(\mathbf{m g} / \mathbf{k g})$ & Number of Crossings \\
\hline Control & - & $40.0 \pm 7.2$ \\
\hline EBPC & 30.0 & $39.1 \pm 7.2$ \\
\hline EPA & 2.0 & $45.9 \pm 6.2$ \\
\hline & 4.0 & $54.4 \pm 11.8$ \\
\hline EPB & 2.0 & $68.0 \pm 9.8$ \\
\hline Caffeine & 4.0 & $55.3 \pm 10.9$ \\
\hline
\end{tabular}

The values are expressed as Mean \pm SEM. ANOVA followed Dunnett's test shows $* \mathrm{p}<0.05$ for caffeine treatment compared to control. 
These results suggested that EBPC and EPA could improve the cognition in normal and in amnesia induced rats. The nootropic drugs belong to the category of psychotropic agents with selective effect on intellectual performance, learning and memory (Giurgea, 1973) in presence or in absence of cognition deficit (Poschel, 1988). Thus, the reduction in the escape latency in MWMT suggested that EBPC and EPA extracts of guaraná seeds possessed nootropic activity.

Chronic administration of $10 \mathrm{mg}$ caffeine $/ \mathrm{kg}$ did not alter the escape latency in normal rats in MWMT. However, it could revert the amnesia effect produced by scopolamine. In addition, in this dose, caffeine increased the crossings number in OFT, whereas both doses tested of EBPC or EPA did not alter its parameter, suggesting a different effect to the compounds. The OFT is a rodent experimental model for study of ambulatory activity (Wash and Cummins, 1976). Psychostimulant drugs increase the ambulatory behavior, showing motor stimulation (Porsolt et al, 1977). In popular medicine, caffeine is generally considered a psychostimulant and to reduce fadigue (Benowitz, 1990).

There is a controversy about the role of caffeine and xanthines in learning and memory process. Different studies have reported that caffeine improved (Howell et al, 1997; Pollina and Calev, 1997), impairs (Fisher and Gillet, 1997) or did not affect (Smith et al, 1994) memory aspects. Angelucci et al (1999) observed that caffeine differentially affect the memory process and this effect could was dependent of particularities of the memory task under study.

The results observed in the MWMT did not reflect a general increase in motor activity due to chronic administration of EBPC and EPA extracts, since the same doses which induced increase in cognition and anti-amnesia effect, produced no increase ambulatory behavior in the OFT. In young and elderly normal volunteers, acute or chronic administration of guaraná produced no effects on cognition (Galduroz and Carlini, 1994; 1996)

Mattei et al (1998) and Espinola et al (1997) reported increase in physical capacity, and antiamnesia effects in rats and mice treated with guaraná seeds extract. However, rats treated with caffeine in a dosage similar to the amount found in the guaraná extract did not show betterment of their physical and mental performances (Espinola et al, 1997), suggesting that these effects were due to components present in the extract different from caffeine. Saponins and tannins are known as active substances responsible for enhancing cognitive behavior observed with red ginseng (Simeray et al, 1982; Yoshizawa et al, 1987; Ying et al, 1994).

In our experiments, EPB did not alter any parameter analyzed, suggesting that this fraction did not contain the active components responsible for the nootropic effect observed with EBPC or EPA. Changes in body weight of the rats undergoing treatment were analyzed during chronic administration of different doses of EBPC, EPA and caffeine. Compared to the control group, no significant variations were seen. During the experimental period, the animals did not show mortality in the different treatment groups. The post-mortem examination revealed no alteration in the general aspect and weight of the heart, liver, spleen and kidneys to different doses of EBPC, EPA or caffeine compared to control (data not shown).

In conclusion, the present study showed that EBPC and EPA extracts of guaraná seeds was active orally and exhibited significant nootropic effect. Natural compounds that exert this property in tests in vivo might offer a useful therapeutic choice in the prevention and/or treatment of the memory deficits such as those seen in Alzeimer's or Parkinson's diseases.

\section{ACKNOWLEDGMENTS}

This work was supported by CNPq grants.

\section{RESUMO}

O efeito do tratamento crônico (gavagem) do extrato bruto liofilizado (EBPC) das sementes da Paullinia cupana, guaraná, e seus constituintes semi-purificados EPA e EPB, sobre o comportamento cognitivo foi estudado em ratos submetidos ao teste do labirinto aquático de Morris. EBPC $(30.0 \mathrm{mg} / \mathrm{kg})$ e EPA $(2.0 \mathrm{mg} / \mathrm{kg})$, mostraram menor latência para encontrar a plataforma submersa quando comparados ao grupo controle (salinat tween 80 a $0.2 \%$ ), em ratos normais ou tratados com escopolamina, o que sugere efeito benéfico sobre a cognição. Estes extratos não alteraram a atividade locomotora no teste do campo aberto. A cafeína, reduziu o tempo 
de latência para encontrar a plataforma submersa no teste do labirinto aquático de Morris em tratados com escopolamina. Além disso, aumentou o número de cruzamentos no teste do campo aberto, mostrando efeito estimulante. Ratos tratados com EPB não produziram alteração significativa nos testes utilizados. Os animais tratados cronicamente com EBPC, EPA ou EPB tiveram a mesma evolução ponderal e sobrevida 0 que sugere baixa toxicidade para os extratos.

\section{REFERENCES}

Angelucci, M. E. M.; Vital, M. A. B. F.; Cesário, C.; Zaduski, C. R.; Rosalen, P. L. and Cunha, C. (1999), The effect of caffeine in animal models of learning and memory. Eur J. Pharmacol., 373, 135-140.

Benowitz, N. L. (1990), Clinical pharmacology of caffeine. Ann Rev. Pharmacol., 41, 277-288.

Espinola, C.B.; Dias, R.F.; Mattei, R.; Carlini, E.A. (1997), Pharmacological activity of Guaraná (Paullinia cupana, Mart.) in laboratory animais. $J$ Ethnopharmacol., 223-229.

Fisher, S.; Guillet, R. (1997), Neonatal caffeine alters passive avoidance retention in rats in an age and gender related manner. Brain Res., 98, 145-149.

Galduroz, J. C. F. and Carlini, E. A. (1994), Acute effects of the Paulínia cupana, "Guaraná" on the cognition of normal volunteers. São Paulo Medical Journal/RPM, 112 : (3), 607-611.

Galduroz, J. C. F. and Carlini, E. A. (1996), The effects of long-term administration of guaraná on the cognition of normal, elderly volunteers. São Paulo Medical Journal/RPM, 114 : (1), 1073-1078.

Giurgea, C. (1973), The nootropic approach to the pharmacology of the integrative action of the brain. Cond. Reflex., 8, 108-115.

Henman, A. (1982), Vida natural - o guaraná: sua cultura, propriedades, formas de preparação e uso. $2^{\text {nd }}$ ed. [S.1.]: Global/Groun.

Howell, L. L.; Coffin, V. L. and Spealman, R. D. (1997), Behavioral and physiological effects of xanthines in nonhuman primates. Psychopharmacol (Berlin), 129, 1-14.

Lee, S. C.; Moon, Y. S. and You, K. H. (2000), Effect of red ginseng saponins and nootropic drugs on impaired acquisition of ethanol-treated rats in passive avoidance performance. J. Ethnopharmacol., 69, 1-8.

Mattei, R.; Dias, R. F. and Espínola, E. B. (1998), Guaraná (Paullinia cupana): toxic behavioral effects in laboratory animals and antioxidant activity in vitro. J Ethnopharmacol., 60, 111-116.

Morris, R. (1984), Development of a water-maze procedure for studing spatial learning in the rat. J. Neurosc. Meth., 11, 47-60.
Nadkarni, A. K. (1996), Nadkarni's Indian material medica. Bombai: Popular Prakashan. v. 1. pp. 296-666.

Porsolt, R. D.; Le Pichon, M. and Jafre, M. (1977), Depression: a new animal model sensitive to antidepressant treatments. Nature, 266, 730-732.

Poschel, B. P. H. (1988), In: Iversen, S. D. and Snyder, S. D. (Eds.). Handbook of Psychopharmacology. New York: Plenum. v. 20. pp. 437-445.

Pollina, D. A. and Calev, A. (1997), Amnésia associated with eletroconvulsive terapy- progress in pharmacological prevention and treatment. CNS Drugs, 7, 381-387.

Royce, J. R. (1977), On the construct validity of OpenField measures. Psychol Bull., 84 : (6), 1098-1106.

Simeray, J.; Chaumont, J. P.; Bevalot, F. and Vaquete, J. (1982). Les proprietés antifongiques des cistacées et plus particulièrment de Cistus laurifolius L.:role dês tanin non hydrolysable. Fitoter., 53, 45-48.

Smith, A.; Maben, A. and Brockman, P. (1994). Effects of evenning meals and caffeine on cognitive performance, mood and cardiovascular functioning. Appetite, 22, 57-65.

Ying, Y.; Zang, J. T.; Shi, C. Z. and Liu, Y. (1994), Study on the nootropic mechanism of ginsenoside $\mathrm{Rb} 1$ and Rb1-influene on mouse brain development. Acta Pharm Sin., 29, 241-245.

Yoshizawa, S.; Horiuchi, T., Fujiki, H., Yoshida, T.; Okuda, T. and Sugimura, T. (1987), Antitumor promoting activivity of (-) epitallocatechine gallate, the main constituint of tannin in green tea. Phytot. Res., 1, 44-47.

Wash, R. N. and Cummins, R. A. (1976). The open-field test: a critical review. Psychol. Bul., 86, 482-504.

Received: July 09, 2004; Revised: November 18, 2004; Accepted: May 23, 2005. 